\title{
Fuzzy Logic Procedure for Drawing up a Psychological Profile of Learners for Better Perception in Courses
}

\author{
Krasimir Slavyanov \\ Department Computer Systems and \\ Technologies \\ "Vasil Levski" National Military Uni- \\ versity \\ Shumen, Bulgaria \\ k.o.slavyanov@gmail.com
}

\begin{abstract}
This article offers an original classification procedure based on Mamdani fuzzy inference system (FIS) dedicated to compute multiple criterions each from different type of psychological profiles. The modelling and information analysis of the FIS are developed to draw a general conclusion from several psychological criterions in order to provide better pre-course lecturer preparation and thus better students' perception. Simulation experiments are carried out in MATLAB environment.
\end{abstract}

Keywords-fuzzy inference system, fuzzy rule, membership function, psychological profile.

\section{INTRODUCTION}

It is important for short-term courses to teach the learning material in the most understandable way for learners. From this point of view, a brief survey or study could be used to quickly classify learners and, accordingly, select the most receptive style of teaching to achieve quick results with minimal effort.

People learn knowledge in different ways and the new technologies can be successfully implemented for the education improvement [1]. Howard Gardner has developed the theory of eight different types of intelligence, and it is widely used in education by then until now. Gardner believes that: All human beings possess all eight types of intelligence in varying degrees. Every person is intellectually built on different way. We can improve education by working with many types of intelligence of their students. The types of intelligence are as follows: linguistic, logical-mathematical, visualspatial, musical, body-kinetic, interpersonal, natural and intrapersonal [2].

The basic idea in Gardner's theory about the many types of intelligence is that each person learns in their own way. Some students need to read text to understand the information, while others need to hear information in the form of a lecture. Other best learn some information through charts or pictures. This does not mean that they study only one specific way, but they are usually stronger in some respects and weaker in others. All students possess all kinds of intelligence. The predominant intelligences in the group can be quickly detected with artificial intelligence technologies like Fuzzy Inference Systems / FIS/ for implementation of a fuzzy rules ([2], [3], [4]), like for resolving similar problems ([5], [6], [7], [8], [9], $[10])$. In this paper, one possible way to analyse a precourse survey results with a Fuzzy Inference System is explained. Furthermore, this approach can be successfully implemented in Human Resources Management systems ([11], [12], [13]) or easily adopted to some existing HR methods [14].

\section{MATERIALS AND METHODS}

\section{Preconditions.}

Taking this paper thematic under consideration, the well-detailed Bloom's Taxonomy of Educational Objectives can be used for the input variables in the dedicated FIS. According to that taxonomy, the educational learning objectives can be classified into levels of complexity and specificity. These levels are determined as follows: Remembering; Understanding; Applying; Analysing; Evaluating; Creating [15]. For the current purpose a cross table between Gardner's intelligences and Bloom's Taxonomy is developed and shown on Table 1.

The psychological profiles for the FIS procedure are taken to be the types of intelligence. The Classification of Educational Goals in each level are filled with the corresponding action for each type of intelligence. This action can be valued between zero and one. The resulting profile for a student is proposed to be one of a seven - for all of the Gardner's intelligences.

Building a system for making the intelligence type decision based on fuzzy logic.

The fuzzy logic tools that can be used (in Matlab environment) are of two approaches for implementing a decision-making system (Sugeno and Mamdani types of Fuzzy Inference). The membership functions in FIS tools are of many types regarding the way in with each entrance variable is forming the affiliation degree for the output. 
TABLE 1

GARDNER'S INTELLIGENCES /VERTICALLY/ AND BLOOM's TAXONOMY /HORIZONTALLY/

\begin{tabular}{|c|c|c|c|c|c|c|}
\hline & REMEMBERING & UNDERSTANDING & APPLYING & ANALYSING & EVALUATING & CREATING \\
\hline $\begin{array}{l}\text { Verbal } \\
\text { Linguistic }\end{array}$ & $\begin{array}{c}\text { Dialogue } \\
\text { or monolog } \\
\text { performance }\end{array}$ & $\begin{array}{c}\text { Fill in a } \\
\text { characterization } \\
\text { sheet }\end{array}$ & $\begin{array}{c}\text { Write a } \\
\text { letter, notes }\end{array}$ & $\begin{array}{l}\text { Identify } \\
\text { the key } \\
\text { features of } \\
\text { the task }\end{array}$ & Write a review & $\begin{array}{c}\text { Write } \\
\text { methodology }\end{array}$ \\
\hline $\begin{array}{l}\text { Logical- } \\
\text { mathematical }\end{array}$ & $\begin{array}{c}\text { Construct a } \\
\text { rules }\end{array}$ & $\begin{array}{l}\text { Draw up a grid } \\
\text { of attributes }\end{array}$ & $\begin{array}{c}\text { Interpret } \\
\text { directions } \\
\text { and draw up } \\
\text { plans }\end{array}$ & $\begin{array}{c}\text { Convert } \\
\text { the plans, } \\
\text { measure } \\
\text { and divide } \\
\text { up the desk } \\
\text { board }\end{array}$ & $\begin{array}{l}\text { Supervise the } \\
\text { accuracy with } \\
\text { mathematics }\end{array}$ & $\begin{array}{l}\text { Design the } \\
\text { set to be built } \\
\text { precisely }\end{array}$ \\
\hline Visual Spatial & Find pictures & $\begin{array}{l}\text { Make a picture, } \\
\text { sketch }\end{array}$ & $\begin{array}{l}\text { Design fig- } \\
\text { ures, graphi- } \\
\text { cal models }\end{array}$ & $\begin{array}{l}\text { Interpret } \\
\text { the } \\
\text { directions, } \\
\text { light }\end{array}$ & $\begin{array}{l}\text { Draw result } \\
\text { charts }\end{array}$ & $\begin{array}{c}\text { Create } \\
\text { graphics with } \\
\text { visual impact }\end{array}$ \\
\hline $\begin{array}{l}\text { Bodily } \\
\text { Kinesthetic }\end{array}$ & $\begin{array}{c}\text { Follow } \\
\text { instructions }\end{array}$ & $\begin{array}{c}\text { Develop } \\
\text { appropriate } \\
\text { movements and } \\
\text { gestures }\end{array}$ & $\begin{array}{c}\text { Gesture } \\
\text { performance, } \\
\text { moves, }\end{array}$ & $\begin{array}{l}\text { Compare } \\
\text { the moves }\end{array}$ & $\begin{array}{l}\text { Evaluate } \\
\text { changes in } \\
\text { time and } \\
\text { movements }\end{array}$ & $\begin{array}{l}\text { Divide work } \\
\text { into steps }\end{array}$ \\
\hline Musical & $\begin{array}{l}\text { Look for music } \\
\text { or sound }\end{array}$ & $\begin{array}{l}\text { Select appro- } \\
\text { priate sound } \\
\text { effects }\end{array}$ & $\begin{array}{l}\text { Operate the } \\
\text { sound for the } \\
\text { performance }\end{array}$ & $\begin{array}{l}\text { Discuss in } \\
\text { sounds, } \\
\text { intonation }\end{array}$ & $\begin{array}{l}\text { Adding sounds } \\
\text { in results ex- } \\
\text { pression }\end{array}$ & $\begin{array}{l}\text { Compose } \\
\text { like for } \\
\text { orchestra }\end{array}$ \\
\hline Interpersonal & $\begin{array}{c}\text { Keep a logbook } \\
\text { of all others } \\
\text { activities }\end{array}$ & $\begin{array}{l}\text { Group, discuss, } \\
\text { forum }\end{array}$ & $\begin{array}{c}\text { Interact with } \\
\text { other, team } \\
\text { work }\end{array}$ & $\begin{array}{c}\text { Analyze } \\
\text { interactions } \\
\text { and devel- } \\
\text { opment }\end{array}$ & $\begin{array}{l}\text { Assess connec- } \\
\text { tions in results }\end{array}$ & $\begin{array}{l}\text { Design each } \\
\text { module } \\
\text { in group } \\
\text { manner }\end{array}$ \\
\hline Intrapersonal & $\begin{array}{l}\text { Write a recount } \\
\text { of everything }\end{array}$ & $\begin{array}{l}\text { White a } \\
\text { self-learning } \\
\text { path }\end{array}$ & $\begin{array}{c}\text { Take the } \\
\text { lesson on an } \\
\text { emotional } \\
\text { journey }\end{array}$ & $\begin{array}{l}\text { Analyze } \\
\text { each } \\
\text { object's } \\
\text { behavior }\end{array}$ & $\begin{array}{l}\text { Find Indepen- } \\
\text { dencies }\end{array}$ & $\begin{array}{l}\text { Design in } \\
\text { one object } \\
\text { behavior }\end{array}$ \\
\hline Naturalist & $\begin{array}{l}\text { Write a list of } \\
\text { locations }\end{array}$ & $\begin{array}{c}\text { Use natural } \\
\text { world examples }\end{array}$ & $\begin{array}{l}\text { Perform a } \\
\text { scene of } \\
\text { the task } \\
\text { outdoors }\end{array}$ & $\begin{array}{c}\text { Analyze the } \\
\text { nature }\end{array}$ & $\begin{array}{l}\text { Evaluate } \\
\text { with nature } \\
\text { similarity }\end{array}$ & $\begin{array}{l}\text { Design } \\
\text { recycling } \\
\text { systems and } \\
\text { backups }\end{array}$ \\
\hline
\end{tabular}

The experiments in Matlab environment are carried out with the fuzzy logic tool and the use of Gaussian type of membership functions, because of the factors: the chosen type of classification; the possible similarity in many student results; universality of application of Gaussian functions; evenness of the shape; values other than zero for all points. The subdivision of the Gaussian curves by their form includes a simple Gaussian curve and a two-way combination in type "bell" (Fig. 1).

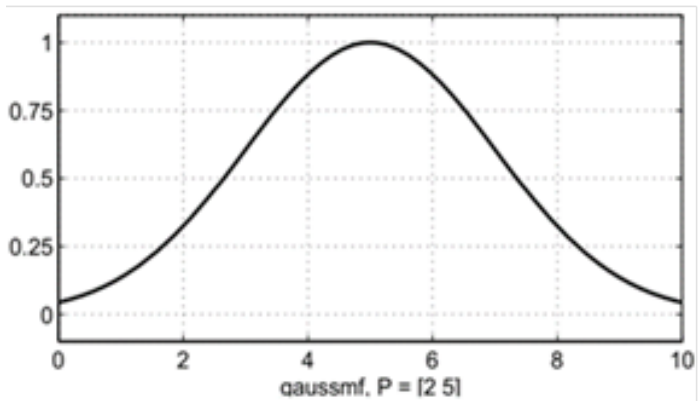

(a)

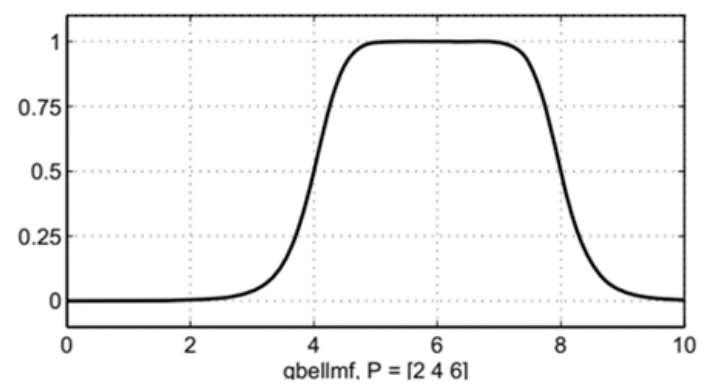

(b)

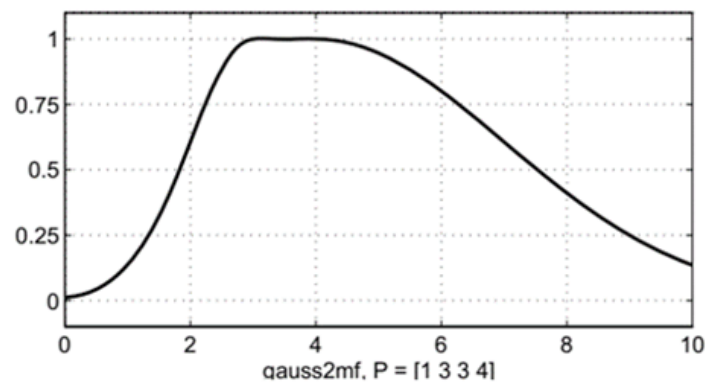

(c)

Fig.1 Graphics of the functions belonging to the Gaussian distribution - plain (a), type "bell" and combination (c). 
The degree of membership of a learner to the Gardner's intelligences is from zero to one, by the value of membership. In this way, the fuzzy inputs can be associated with a positioning rule in the membership

function area. To form the resulting Gardner's intelligence for each learner, the decision making method for the FIS is chosen to be of Mamdani's type [16], because the output variable is designed to be number and the output membership functions are fuzzy sets like the input ones. The maximum value in every membership function is used for the aggregation model for the FIS input variables.

Following the Bloom's Taxonomy for the learner's complex intelligence profile, each of the levels' profile is selected to make the final defuzzification decision of the type "largest of maximum". These parameters of the FIS are designed to summarize the results of the six Bloom's Taxonomy levels for every learner examined. The system build in Matlab is shown on Fig. 2.

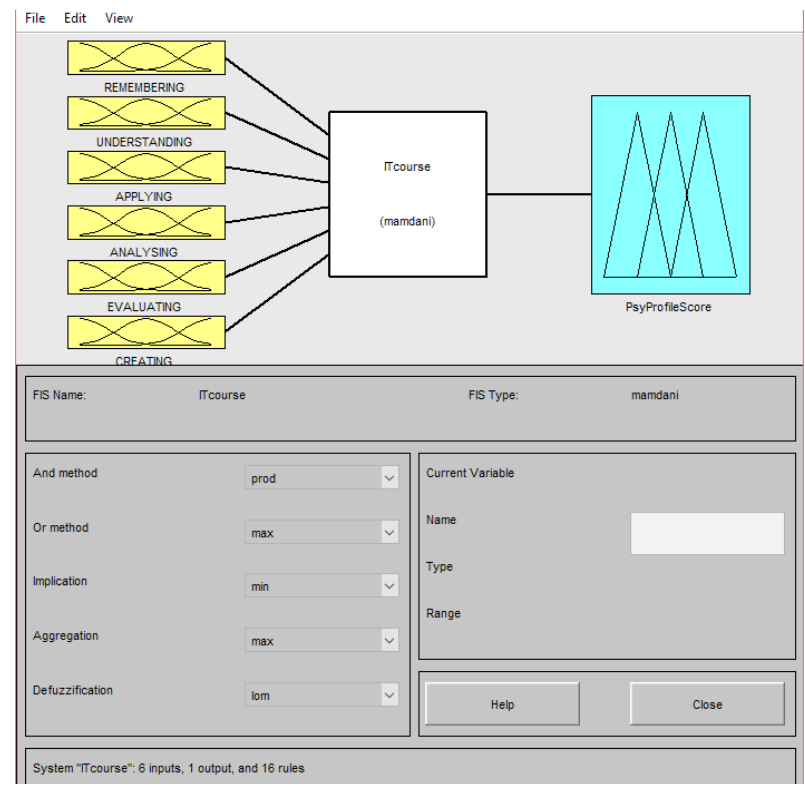

Fig. 2. Block diagram of the FIS for learner profile decision making by means of the Mamdani method, built in Matlab.

The input variables on the left side of the system are six, corresponding to each of the Bloom's Taxonomy levels used to classify the learner in the resulting Gardner's intelligence psychological profile. Each of the input variables is made of membership functions developed in order to correspond for the psychological profile. The output variable is a combination of all the rules applied to the input variables and is the person's intelligence type that best satisfied the rules.

The applied shape of the curve membership function to each input fuzzy set is of Gaussian combination type. The results for each of the Bloom's taxonomy levels (Remembering; Understanding; Applying; Analysing; Evaluating; Creating) should fall within eight fuzzy sets defined by the functions of belonging in the range of 0 to 8 . Each sector is formed in manner $0-1,1-2$, and $2-3$ until 7-8 in the same sequence as the output values of the Gardner's intelligence indicators (table 1.). For example the results for the Bloom's Understanding level are designed to fall in the membership functions: Fill tables; Draw grid; Make pictures; Develop movements; Sounds; Forum; Self path; Nature examples (fig. 3)

The tailor made form of these functions is to use maximum space in the range $0-8$ to fall into the fuzzy sets for higher percentage results from the input value. Therefore, the increase of the impact of the indicator is designed to increase the degree of belonging to the elements of the fuzzy set. Similar are the parameters of input variables for the results for the other Bloom levels. In this paper, they are not described in detail but all are followed by the crossings in table 1 . The fuzzy variable for output is developed of fuzzy sets, again in the range $0-8$, given the intelligence type.

The membership functions are with the Gaussian distribution of type "bell", designed to summarize at maximum the results for each student's score (variables), classified by Gardner rules. The rules developed for the operation of FIS are 16, divided into 2 groups, the weight of every rule of the groups is 1.(fig. 5).

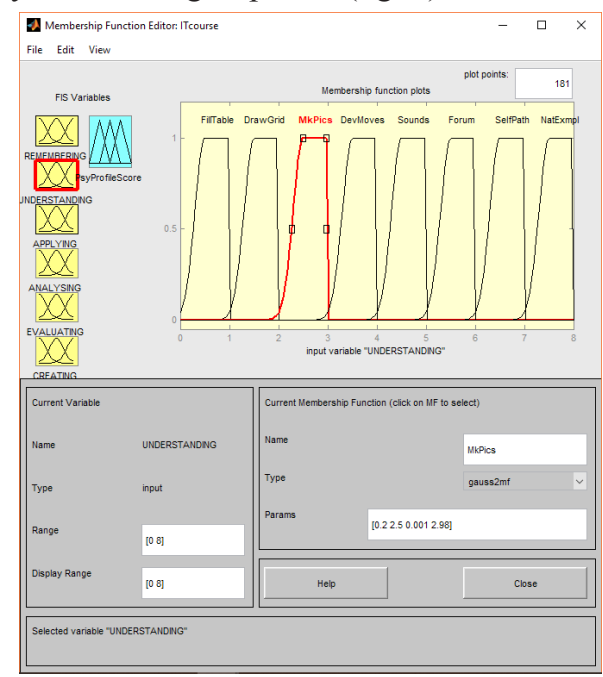

Fig. 3. Diagram describing the membership functions of fuzzy set corresponding to the variation in criteria for level Understanding

The functions for the fuzzy sets of the output variable - Profile Score, are shown on figure 4.

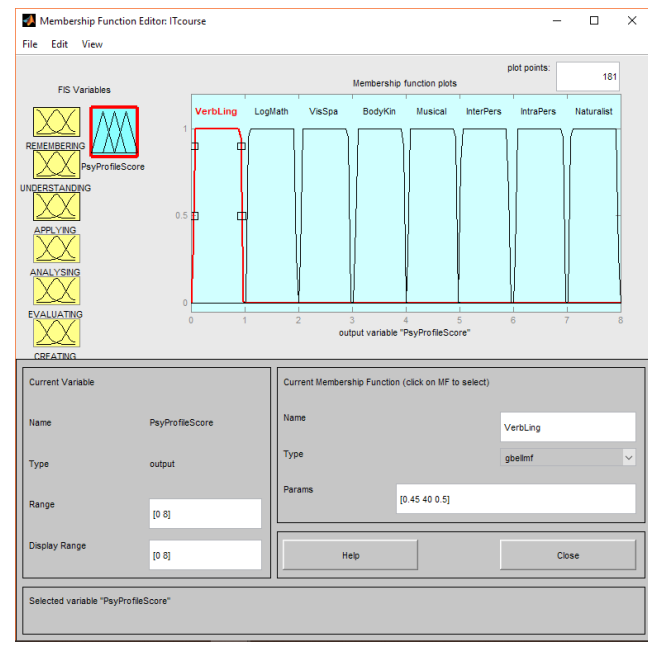

Fig. 4. Diagram of membership functions of Gaussian type "bell" for the fuzzy sets of the output variable corresponding to the student's intelligence type score. 
For the rules from 1 to 8 , each learner's intelligence type is described with selected fuzzy set functions of input variables that describe it's Bloom level characteristics (Remembering; Understanding; Applying; Analyzing; Evaluating; Creating) (Table 1).

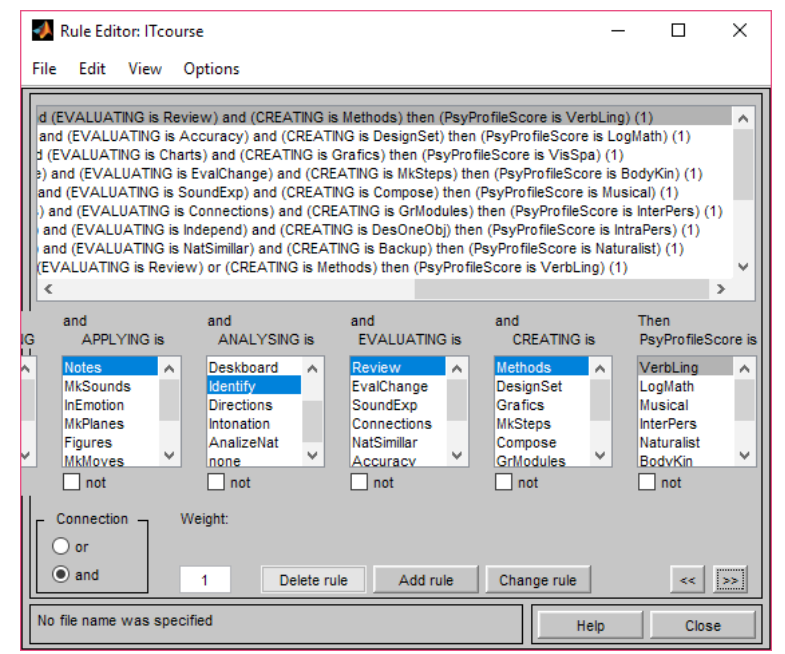

Fig. 5. Tool with Fuzzy system rules for psychological profile decision-making process of a system with fuzzy logic simulated in
Matlab

The operation used for the various fuzzy sets, which are obtained for Bloom level characteristic is a logical "AND" to reflect the intersection of these fuzzy sets. One of the rules is used for example:

(Remembering $==$ Rules) \& (Understanding $==$ DrawGrid $) \&$ (Applying $==$ MkPlanes $) \&($ Analyzing $==$ DeskBoard $) \&$ (Evaluating $==$ Accuracy $) \&($ Creating $==$ DesignSet $)=>$ (PsyProfileScore=LogMath)
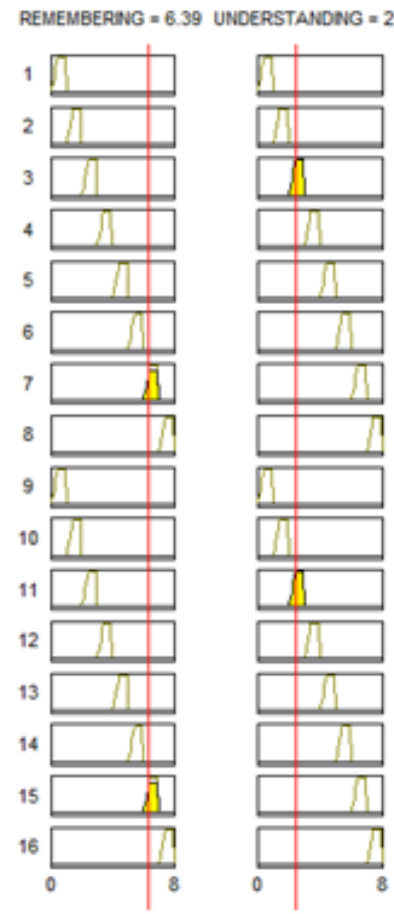

The second eight rules are designed to assess the results of the learner that specify not strong but acceptable results for each Bloom level. The logical operator "AND" is used in these rules for operation between the selected fuzzy sets, therefor to address potential some level exceptions allowed by Gardner's methodology. Following the description, the set of these 8 rules can be explained, with one of them:

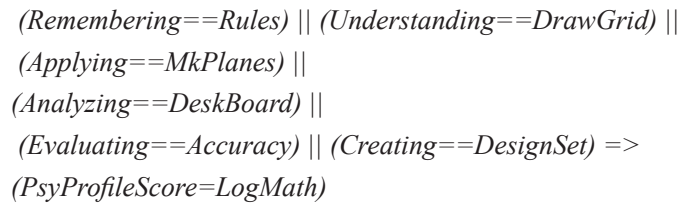

This fuzzy inference system is developed to summarize the results of six Bloom levels, to make fast result as a value corresponding to the combination of degrees of matching the learners' attitude with the Gardner's intelligence types.

\section{Results AND Discussion}

The experimental results are produced for an exemplary learners' psychological intelligence assessment on five Bloom levels as criterions. The psychological profile according the Gardner's intelligence types is decided upon its classification by fuzzy logic. The numerical simulation results of the experiment for a learner's profile with FIS result PsyProfileScore $=2.88$ is depicted on figure 6 .

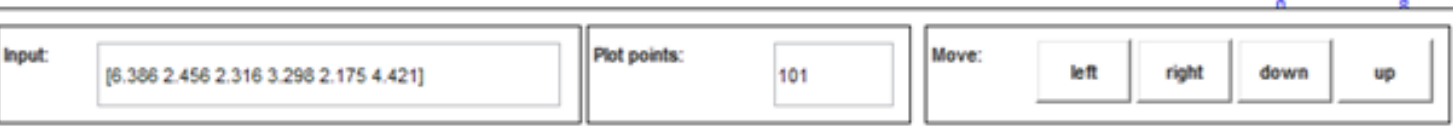

Fig.6. Graphically Matlab FIS expressed results for one exemplary learner in a short-term course. The score 2.88 (blue column) is connected to the output variable with the number 3. The learner's psychological profile in that case is assessed as Visual Spatial. 
The simulation is resulted to the output variable with this number even if not relevant to all of the predefined rules. The learner's psychological profile for a course is classified Visual Spatial, one of the Gardner's intelligences.

\section{CONCLUSION}

The Fuzzy Inference System is developed to summarize the results of all predefined Bloom's taxonomy levels in accordance with a system of rules is established. The input variables are designed to produce pre-course results about the most of the learners' psychological profiles. The flexible approach in formulating the fuzzy membership functions according the Bloom's taxonomy is important for the possible implementation of the developed Fuzzy logic procedure in similar education cases.

A proper analysis of the FIS results can be therefore successfully used in order to indicate which teaching technologies can be implemented for the education improvement purposes in short-term courses. A FIS procedure similar to the offered one can be designed to optimize some other real-time dependent signal processing assessment systems ([17], [18]).

\section{REFERENCES}

[1] Atanasov, V.T., Smart Educational Cluster Conceptualization, Proceedings of International Scientific Conference, Shumen, October 02th -04th, 2018, pp.173-181, ISSN 2367-7902

http://www.aadcf.nvu.bg/scientific_events/dft2018/V.\%20T.\%20 Atanasov.pdf

[2] Gardner H., Frames of Mind: The Theory of Multiple Intelligences, New York : Basic Books, (C1983. ISBN-978-0-465-02433-9, https://doi.org/10.1177/001698628502900212

[3] Zadeh, L.A., Outline of a new approach to the analysis of complex systems and decision processes, IEEE Transactions on Systems, Man, and Cybernetics, Vol. 3, No. 1, Jan. 1973, pp. 28-44. https:// doi.org/10.1109/TSMC.1973.5408575

[4] Zadeh, L.A., Fuzzy logic, Computer (Volume: 21, Issue: 4, April 1988), pp. 83 - 93. https://doi.org/10.1109/2.53

[5] Al Ganideh S. F.; El Refae G. A., Socio- psychological variables as antecedents to consumer ethnocentrism: A fuzzy logic based analysis study, 2010 Annual Meeting of the North American Fuzzy Information Processing Society, 12-14 July 2010, ISBN: 978-1-4244-7858-3，2010,1-6. https://doi.org/10.1109/ NAFIPS.2010.5548274

[6] Lefly M., Austin V., Match'em: using fuzzy logic to profile criminals, Proceedings of 6th International Fuzzy Systems Conference, 1997, vol.1, 305 - 311. https://doi.org/10.1109/ FUZZY.1997.616386

[7] Di Nuovo A., Di Nuovo S., Buono S., Cutello V., Benefits of fuzzy logic in the assessment of intellectual disability, 2014 IEEE International Conference on Fuzzy Systems (FUZZ-IEEE), 2014, $1843-1850$.

https://doi.org/10.1109/FUZZ-IEEE.2014.6891834
[8] Zhang J., Wang X., Mahfouf M., Linkens D.A., Fuzzy Logic based Identification of Operator Functional States Using Multiple Physiological and Performance Measures, 2008 International Conference on BioMedical Engineering and Informatics, 2008 , Vol.1, $570-574$ https://doi.org/10.1109/BMEI.2008.181

[9] Petrova A. K., Methods and algorithms of decision making support in the process of experts' qualification evaluation for the completion of centers of professional certification, 2017 IEEE II International Conference on Control in Technical Systems (CTS), $2017,384-386$ https://doi.org/10.1109/CTSYS.2017.8109575

[10] Fernandez S., Ito T., Driver classification for intelligent transportation systems using fuzzy logic, 2016 IEEE 19th International Conference on Intelligent Transportation Systems (ITSC), 2016, $1212-1216$

https://doi.org/10.1109/ITSC.2016.7795711

[11] Hosseininezhad F., Hosseininezhad F., Balalpour M., A Fuzzy Expert System for performance evaluation of HRM with 360 degree feedback approach (Case study: An Iranian IT company), Computer Sciences and Convergence Information Technology (ICCIT), 6th International Conference, Dec. 2011. https://ieeexplore. ieee.org/document/6316664

[12] Doctor F., Hagras H., Roberts D. Callaghan V., A type-2 fuzzy based system for handling the uncertainties in group decisions for ranking job applicants within Human Resources systems, Fuzzy Systems, FUZZ-IEEE 2008, 2008, 481 - 488. https://doi. org/10.1109/FUZZY.2008.4630412

[13] Slavyanov K.O., An algorithm of fuzzy inference system for human resources selection tools, "Society. Integration. Education", Proceedings of the International Scientific Conference. Volume V, Rezekne, May 25th-26th, 2018. 445-454. http://dx.doi. org/10.17770/sie2018vol1.3311

[14] Vasileva M., Lambeva M., "Intelligent methods for attestation of scientific and teaching staff. Rasch model", Proceedings of the 11th International Scientific and Practical Conference "Environment. Technology. Resources", June 15-17, 2017, Rezekne, Latvia, Volume II, pp 171 - 175,

http://dx.doi.org/10.17770/etr2017vol2.2665

[15] Bloom B.S., Engelhart M.D., Furst E.J., Hill W.H., Krathwohl, D.R., Taxonomy of Educational Objectives: The Classification of Educational Goals, Handbook I: Cognitive domain. New York: David McKay Company, 1956

[16] Mamdani E.H., Assilian S., An experiment in linguistic synthesis with a fuzzy logic controller, International Journal of Man-Machine Studies, Vol. 7, No. 1, 1975, pp. 1-13.

https://doi.org/10.1016/S0020-7373(75)80002-2

[17] Nikolov, L. "Wireless Network Vulnerabilities Estimation", International Scientific Journal "Security and Future", Vol. 2 (2018), Issue 2, pg(s) 80-82 http://confsec.eu/sbornik/cs-2-2018.pdf

[18] Bedzhev B., Tasheva Z., Stoyanov B., Bogdanov R., An algorithm for lossless signal processing (2007) Proceedings of the Third Workshop - 2005 IEEE Intelligent Data Acquisition and Advanced Computing Systems: Technology and Applications, IDAACS 2005, art. no. 4062184, pp. 498-502. https://doi.org/10.1109/ IDAACS.2005.283033 